\title{
The Indicators of Nurse's Perspective in Health Management System and Hospital Safety in Gombong Region Hospitals, Indonesia
}

\author{
Wulan Rahmadhani ${ }^{1 *}$, Nur Azis Rohmansyah ${ }^{2}$, Than Kyaw Soe ${ }^{3}$, Jipri Suyanto ${ }^{4}$ \\ 1*Correspondence Author: wulan@stikesmuhgombong.ac.id \\ ${ }^{1}$ Departement of Midwifery, Sekolah Tinggi Ilmu Kesehatan Muhammadiyah Gombong, Indonesia \\ ${ }^{2}$ Departement of Physical Education, Universitas PGRI Semarang, Indonesia \\ ${ }^{3}$ Water, Sanitation and Hygiene, United Nations Children's Found (UNICEF), Myanmar \\ ${ }^{4}$ Departemen of Public Health, Faculty of Health Science, Dahasen University Bengkulu, Indonesia
}

\begin{tabular}{l}
\hline I N D E X I N G \\
\hline Keywords: \\
Hospital safety; \\
Health management; \\
Nurse.
\end{tabular}

Kata Kunci:

WISN;

Beban kerja;

Tenaga kerja.

\begin{abstract}
A B S T R AC T
Health management systems played a crucial role in hazard reduction and prevention as well as in improving employee performance. The importance of a hospital health and safety management system and there has been no study in Indonesia with the same objective based on the OSHA indicator. The purpose of this study is to evaluate the performance indicators of Hospital Safety and health management systems in hospitals in the Gombong region, Indonesia, in terms of a nurse perspective. The research method used was descriptive-analytic. The sample size consisted of 450 nurses. The questionnaire used a standard questionnaire from hospital safety and health management systems which consisted of 53 questions including 6 domains; Leadership management, Hazard identification, employee participation, Hazard prevention, evaluation and improvement program, and Education and training. Using the 1-4 Likert scale of strongly disagree, disagree, agree, and strongly agree. The highest score was 4 and the lowest score is 1 . Data analysis used SPPS, t-test, and analysis of variance (ANOVA) with a significant value $<0.05$. Based on the research results, poor conditions occurred in several domains except in the domain of employee participation. There were significant variables between hazard identification and gender, hazard prevention and improvement program and evaluation also. Conclusion of this study, hospital administrations need to be improved and pay more attention to occupational safety and health in the workplace. To get rid of weaknesses and a mistake, we need to continuous improvement and effective evaluation of staff in training programs.
\end{abstract}

\begin{abstract}
Health management systems memainkan peranan yang sangat penting dalam pencegahan dan pengurangan bahaya serta peningkatan kinerja karyawan. Pentingnya sistem manajemen keselamatan dan kesehatan rumah sakit dan belum ada penelitian di Indonesia dengan tujuan yang sama berdasarkan indikator OSHA. Tujuan dari penelitian ini untuk mengevaluasi indikator kinerja dari Hospital Safety dan Health manajement systems di Rumah Sakit wilayah gombong di tinjau dari perspertif perawat. Metode penelitian menggunakan deskriptif analitik. Sample size terdiri dari 450 perawat. Kuesioner menggunakan kuesiosioner standar dari hospital safety dan health management systems yang terdiri dari 53 pertanyaan mencangkup 6 domain; Manajemen kepemimpinan, partisipasi karyawan, Identifikasi Hazard, pencegahan Hazard, Pendidikan dan pelatihan, dan evaluasi dan peningkatan program. Menggunakan skala likert 1-4 sangat tidak setuju, tidak setuju, setuju dan sangat setuju. Nilai tertinggi adalah 4 dan skor terendah adalah 1. Analisis data menggunakan $S P P S, t$ test dan analysis of variance (ANOVA) dengan nilai signifikan <0.05. Berdasarkan hasil penelitian kondisi buruk terjadi di bebrapa domain kecuali di domain partisipasi karyawan. Terdapat hubungan yang signifikan antara jenis kelamin dan indentifikasi hazard, pencegahan hazard dan evaluasi dan peningkatan program. Kesimpulan penelitian ini Tampaknya perlu bagi administrasi rumah sakit untuk lebih berupaya dan lebih memperhatikan keselamatan dan kesehatan kerja di tempat kerja. Untuk menghilangkan kesalahan dan kelemahan, kita perlu evaluasi yang efektif, peningkatan berkelanjutan dari program pelatihan staf.
\end{abstract}

(C) 2021 JMMR. All rights reserved 


\section{INTRODUCTION}

Health management systems played a crucial role in reduction and hazard prevention as well as improved performance efficiency at hospitals (Thungjaroenkul et al., 2007). Hospitals are considered an important component of the health system of a country where many problems that arise. Hence, we could not revamp the health care system without trying also studying for improve their performance (Zwanziger et al., 2010). The role of health promotion was changed in hospitals, it is no longer limited in giving services for the patients. Although patient safety was currently a fundamental problem around the world, safety is not only limited to patients, also included other aspects such as; employee health and safety (Laverty et al., 2012).

The objectives of health management system and implementing a safety in hospitals are to hold and enhance the physical, social and mental health of all employees, and to protect them from risk at workplace (Abdullah \& Spickett, 2009). World Health Organization (WHO) has taken into considered about health and protection management systems in its policy since it was founded thru the method of "Occupational health for all," it become play a giant position in improving and retaining occupational health (Parand et al., 2014). According to WHO, occupational safety and health is a multidisciplinary interest that purpose to: (1) protect and sell workers' health by preventing and controlling occupational sicknesses and injuries that cast off element and situation of labor which are dangerous to health and safety in the workplace; (2) enhancing workers' physical, social and intellectual wellness and support for the improvement and renovation in their running capacity, in addition to experts and social improvement in the workplace; and (3) study, manipulate and assessment of environmental strain elements in the workplace to lessen ailments and accidents and health problems also improve employee performance (Glickman et al., 2007).

As people who provide care to patients, workers in health services will be exposed to hazards at work. Healthcare professionals are a completely risky profession, in particular for folks who direct touch with sufferers in hospitals, psychotherapy facilities and remedy facilities. According to a file posted with the aid of using the Occupational Safety and Health Administration (OSHA) in 2011, healthcare personnel have experienced 253.700 work releted injuries and illnesses in hospitals, 6.8 injuries and illnesses for every 100 full-time employees. This case has almost doubled in personal enterprise and even higher for production employees (Ford \& Tetrick, 2011). In this case, Denis et al said that a huge a part of the scientific nurse community, and thinking about numerous expert roles hey play which encompass a huge style of sports associated with care in exclusive components of the clinic and community, therefore, nurses are the maximum prone institution this is uncovered to occupational hazards (Dhaini et al., 2016).

The healthcare system s step by step spotting the truth that aside from lowering harm, enhancing worker protection has many benefits. A variety of research have proven that the use of suitable worker protection applications and protocols can lessen fees and worker turnover rates, enhance affected person pleasure and outcomes, and guard the recognition of fitness care organizations (Landsbergis, 2003). Employee protection protocols and applications assist to guard medical experts in opposition to place of job threats, work-associated injuries, infections, ailments and natural (potential) crises. The goal of worker protection is to hold the protection of doctors, nurses, midwives, managers, and different personnel which will assist sufferers in order to attain higher medical outcomes (Latif et al., 2013).

OSHA has added 6 primary factors or signs for comparing medical institution protection overall performance which encompass Leadership Management, worker participation, Hazard Identification, Hazard prevention, Education and training, and assessment and development program. Therefore, to attain the goal of protection and fitness with inside the workplace, better performance and effectiveness of occupational protection and fitness programs, hospitals and fitness facilities are had to pay greater interest to the making plans and implementation of the signs noted above (OSHA, 2018). Because of the importance of hospital safety and health management systems and there was no studies in Indonesia with the equal goal primarily based totally on OSHA signs, then the researchers carried out this have a 
look at which targets to assess the overall performance signs of Hospital Safety and Health control structures primarily based totally at the nurse's perspective.

\section{RESEARCH METHODS}

Analytical descriptive study was used in this study. This research was conducted in a hospital in the Gombong region, Indonesia, in 2019 which aims to evaluate the performance indicators of the Health management systems and Hospital Safety based on nurse's perspective. The sample size consisted of 450 nurses working in different hospital units. Inclusion standards had been willingness to take part and had as a minimum $1 \mathrm{yr}$ of labor enjoy withinside the medical institution. The best exclusion criterion became reluctance to take part. To put into effect ethics, participation became voluntary, first and final names had been now no longer recorded at the questionnaire and the researcher's permission became acquired from the medical institution administration. The data collection tool used a standardized assessment questionnaire from the hospital health and safety management system designed by OSHA. There were 53 questions including six domains, namely Leadership management (eight questions), worker participation (eleven questions), Hazard Identification (eleven questions), Hazard prevention (eight questions), Education and training (10 questions), and assessment and development program (6 question).

Each object turned into rated from 1 to four on a Likert scale: Strongly disagree, Disagree, Agree, strongly agree; four is the very best and 1 is the bottom score. The unique questionnaire turned into in English, which the researchers translated into Indonesian To ensure its validity, the researchers used the free translation method, which means that after the initial translation into Indonesian, the questionnaire was revised by the senior nurse several times and every time the corrections that needed to be corrected were related words. After applying the modifications suggested by professionals, a final draft was prepared. To evaluate the translated text, 10 professional nurses assessed the questionnaire and verified the validity of its contents. To determine its reliability of the questionnaire that was distributed among 30 nurses in the hospital of Gombong region for further study. The results of this pilot study revealed Cronbach of 0.89. Data analysis was performed through SPSS using descriptive statistics, analysis of variance (ANOVA) and $t$ test. The level of significance was set at $\mathrm{P} \leq 0.05$.

\section{RESULT AND DISCUSSION}

The result is showed finding in the analysis process. The finding was the critical answer related to research questions. The finding has supported the study that divided three include proportion, standard deviation, and correlation. The first was the proportion that showed the prevalence of each variable in the study. The goal was found to measure between groupings in the variable. Based on our findings, $324(72 \%)$ of the respondents were women and $126(28 \%)$ of the respondents were men. The respondent aged mean and standard deviation were $31.6 \pm 6.7$, and their mean work experience was $12.6 \pm 6.5$. The employee frequency distribution is presented in Table 1, divided based on work units;

Table 1. Frequency distribution based on work units in the hospital

\begin{tabular}{|c|c|c|}
\hline Work units & $\mathrm{N}$ & $(\%)$ \\
\hline IGD (Emergency Department) & 83 & 18.5 \\
\hline Internal Medicine Unit & 18 & 4 \\
\hline Operation Room & 47 & 10.5 \\
\hline Puerperium Room & 41 & 9 \\
\hline Coronary Care Unit & 45 & 10 \\
\hline Intensive care unit & 56 & 12.5 \\
\hline Infectious disease unit & 36 & 8 \\
\hline Neonatal Unit & 34 & 7.5 \\
\hline Surgery room & 90 & 20 \\
\hline Total & 450 & 100 \\
\hline
\end{tabular}


The standard deviation (SD) and total mean score for every area domain can be seen in Table 2; the highest mean was associated with employee participation $(24.2 \pm 5.7)$ and the lowest was associated with evaluation program and improvement program $(11.4 \pm 3)$.

Table 2. Standard deviation (SD) and total mean for all Domains

\begin{tabular}{lccccc}
\multicolumn{1}{c}{ Domains } & Mean & SD & Min & Max & N \\
\hline Leadership management & 15.2 & 4.0 & 8.00 & 32.00 & 450 \\
Employee participation & 24.2 & 5.7 & 11.00 & 41.00 & 450 \\
Hazard Identification & 19.3 & 4.6 & 10.00 & 33.00 & 450 \\
Hazard Prevention & 17.9 & 4.0 & 8.00 & 30.00 & 450 \\
Education and training & 17.7 & 3.6 & 10.00 & 30.00 & 450 \\
Evaluation and improvement & 11.4 & 3.0 & 6.00 & 19.00 & 450 \\
\hline
\end{tabular}

Significant relationships have been determined among gender and domains names of hazard identification, hazard prevention and evaluation and improvement program. Women had the highest mean score in this domain (Table 3).

Table 3. Standard Deviation (SD) and mean for the relationship between gender and all domains

\begin{tabular}{|c|c|c|c|c|c|}
\hline \multirow[t]{2}{*}{ Domains } & \multicolumn{2}{|c|}{ Men } & \multicolumn{2}{|c|}{ Women } & \multirow[t]{2}{*}{ p-value } \\
\hline & Mean & SD & Mean & SD & \\
\hline Leadership management & 14.6 & 3.9 & 15.4 & 4.0 & .187 \\
\hline Employee participation & 22.9 & 5.6 & 24.7 & 5.8 & .051 \\
\hline Hazard Identification & 18.3 & 4.4 & 19.8 & 4.6 & .048 \\
\hline Hazard Prevention & 16.8 & 4.2 & 18.4 & 3.9 & .020 \\
\hline Education and training & 17.5 & 3.6 & 17.9 & 3.6 & .495 \\
\hline Evaluation and improvement & 10.5 & 2.7 & 11.7 & 3.1 & .006 \\
\hline
\end{tabular}

There was no significant associated among work experience and the studied domains (Table 4). Each variable had p-value more than 0.05 .

Table 4. Correlation Coefficients among work experience and all domains

\begin{tabular}{lcc}
\multicolumn{1}{c}{ Domains } & The Correlation Coefficient & p-value \\
\hline Leadership management & 0.043 & .542 \\
Employee participation & 0.072 & .310 \\
Hazard Identification & -0.013 & .850 \\
Hazard Prevention & 0.030 & .674 \\
Education and training & 0.033 & .647 \\
Evaluation and improvement & -0.022 & .757 \\
\hline
\end{tabular}

\section{Discussion}

The results of this study illustrated that besides for employee participation, the medical center into terrible circumstance in all different offices. Since our have a look at discovered that the mean overall rating for management leadership changed into low, it changed clear that the hospital administration primary concern, effort, and dedication have been important to the hospital health and safety management plan. Bottani et al said that enforcing powerful occupational safety and health management in the organization will help to solve employee occupational health problems effectively and this will assist as a legal tool as well, likewise effective safety management will increase the extent of organizational safety and consequently lessen harm (Bottani et al., 2009). Harris wrote that "in general, management is relied on with the duty of preserving protection and health in the workplace." Management performs a key position within side the fulfillment; consequently it have to dedicate the time and sources essential to make certain the success of the safety and health program, specific an interest in personal participation and be given suggestion on what desires to be done. The hospital in 
which this studies was conducted had poor performance in the hazard identification domain (Mikes, 2009). In this case, Stone highlighted that "companies have to discover risks and take sensible steps to preserve the health and safety of their employees." They must hold of all incidents and events, inform, teach and train, seek advice from employees, collaborate and coordinate all moves with contractors. Hazard identity is continuous process requiring constant repetition, and the consequences would to be documented and taken into considered via management during strategic planning (Kayden et al., 2014).

Tsai et al stated that management should have strong leadership, be committed to the implementation of safety and health management activities and provide an effective program in this case (Tsai et al., 2015). In the health centers in this study, they had been not in good condition in precise circumstance of teach and training, which discovered that hospital management as well as nursing management and education and infection control supervisors, all should pay extra interest to this problem. In this case, Law et al said that the principle goal of staff education concerning occupational safety and health is to prevent and manage hazards in the workplace and ultimately enhance occupational health and quality (Law et al., 2006).

Jha and Epstein said that managers or employers have to aware of educational needs of employees, offer packages to make sure all personnel are able to observe protection, safety and health regulations, constantly evaluate the system and, if necessary, make corrections to make sure effectiveness (Jha \& Epstein, 2010). Huang et al also stated that it is essential and fundamental that hospitals and health care systems have normal and continuous plans for personal training and education on occupational safety and health management systems; likewise, new employees need to examine the technique of reporting workplace injuries and illnesses. Latest training program have to be furnished annually to protect employee safety. These programs can cover several things; prevention of injury and disease, patient management and ergonomics, protection and risk prevention in the workplace, contamination manipulate and prevention, speedy reaction to fire and natural disasters, chemical protection and equipment safety (Huang \& Tallents, 2006).

Arfanis and Smith explained that effective training helps create a feel of belonging in personnel which therefore will increases their responsiveness to protection in the workplace (Arfanis \& Smith, 2012). In an intervention observe by Wang et al aimed at evaluating the impact of a education program on occupational risk prevention, the results confirmed an increase in the level of awareness of the subjects and an increase in their performance regarding risk prevention. Therefore, hospital health management wishes to pay extra attention to education personnel on expert protection and to take primary and effective steps in this problems (Wang et al., 2003).

Hazard prevention and control is another indicator that needs to be considered in the hospital where this research was conducted. Regarding the manage and prevention of accident risk for health workers, OSHA said that the manage and prevention application ought to be as much as date. Personal protective equipment ought to be supplied in the workplace and personnel ought to be requested to apply it (A. Floyde et al., 2013).

Yassi et al revealed that usage of system that enhancing employee safety during work is one of the maximum vital steps taken to lessen the risk of publicity to workplace pathogens amongst healthcare workers. Using protection system reduces damage and contamination of of as much as $70 \%$ (A. Floyde et al., 2013). The assessment and development of safety and health programs is another field requiring occupational protection and health management attention. The evaluation and revision of employees' occupational protection and health programs should be a continuous system. Employees must take a part participate in the assessment process and that they need to be knowledgeable approximately the methods of strategies of comparing the occupational protection and health program (Johnson \& Baum, 2001).

\section{CONCLUSION}

Safety and health in the workplace played an important role in improving the quality of care, performance, effectiveness. In this study, the overall performance signs of hospital safety and health 
management systems were in negative situation in the domains of management leadership, hazard prevention and control, hazard identification, education and training, as well as assessment and development program. As health facility control performs a key function in regulating and setting up protection and health in the workplace, those problems would to be taken into considered as a strategic priority. For this purpose, steps would be taken in order that employees have an energetic participation in the implementation of health policies, important packages would to be set up constantly, threats to employee safety and health should be defined, diagnosed and constantly evaluated, and preventive, protecting and manipulate steps have be taken and revised if important. Since this study examined to assess overall performance indicators of hospital safety and health management systems is the first of its kind in our country, we recommend that those indicators have to evaluate in different elements of the country as well.

\section{ACKNOWLEDGMENT}

We would like to show our gratitude to everybody who contribute in completion of the study.

\section{REFERENCE}

A. Floyde, G. Lawson, S. Shalloe, R. Eastgate, \& M. D'Cruz. (2013). The design and implementation of knowledge management systems and e-learning for improved occupational health and safety in small to medium sized enterprises. Safety Science, 60, 69-76.

Abdullah, N., \& Spickett, J. (2009). Assessing Employees Perception On Health And Safety Management In Public Hospitals. International, 5(4), 54-72. http://www.bizresearchpapers.com/6. Azimah.pdf

Arfanis, K., \& Smith, A. (2012). Informal risk assessment strategies in health care staff: An unrecognized source of resilience? Journal of Evaluation in Clinical Practice, 18(6), 1140-1146. https://doi.org/10.1111/j.1365-2753.2011.01759.x

Bottani, E., Monica, L., \& Vignali, G. (2009). Safety management systems: Performance differences between adopters and non-adopters. Safety Science, 47(2), 155-162. https://doi.org/10.1016/j.ssci.2008.05.001

Dhaini, S. R., Zúñiga, F., Ausserhofer, D., Simon, M., Kunz, R., De Geest, S., \& Schwendimann, R. (2016). Care workers health in Swiss nursing homes and its association with psychosocial work environment: A cross-sectional study. International Journal of Nursing Studies, 53(April 2013), 105115. https://doi.org/10.1016/j.ijnurstu.2015.08.011

Ford, M. T., \& Tetrick, L. E. (2011). Relations Among Occupational Hazards, Attitudes, and Safety Performance. Journal of Occupational Health Psychology, 16(1), 48-66. https://doi.org/10.1037/a0021296

Glickman, S. W., Baggett, K. A., Krubert, C. G., Peterson, E. D., \& Schulman, K. A. (2007). Promoting quality: The health-care organization from a management perspective. International Journal for Quality in Health Care, 19(6), 341-348. https://doi.org/10.1093/intqhc/mzm047

Huang, H., \& Tallents, G. J. (2006). The output of amplified spontaneous emission lasers. Journal of Quantitative Spectroscopy and Radiative Transfer, 102(3), 425-431. https://doi.org/10.1016/j.aap.2005.07.002

Jha, A., \& Epstein, A. (2010). Hospital governance and the quality of care. Health Affairs, 29(1), 182187. https://doi.org/10.1377/hlthaff.2009.0297 
Johnson, A., \& Baum, F. (2001). Health Promoting Hospitals. 16(3), 281-288.

Kayden, S., Anderson, P. D., Freitas, R., \& Platz, E. (2014). Emergency department leadership and management: Best principles and practice. Emergency Department Leadership and Management: Best Principles and Practice, 1-359. https://doi.org/10.1017/CBO9781139030557

Landsbergis, P. A. (2003). The changing organization of work and the safety and health of working people: A commentary. Journal of Occupational and Environmental Medicine, 45(1), 61-72. https://doi.org/10.1097/00043764-200301000-00014

Latif, M. S., Mushtaq, A., Muhammad, Q., Ferdoos, A., \& Hummayoun, N. (2013). Impact of employee' s job satisfaction on organizational performance. European Journal of Business and Management, 5(5), 166-171.

Laverty, A. A., Smith, P. C., Pape, U. J., Mears, A., Wachter, R. M., \& Millett, C. (2012). High-profile investigations into hospital safety problems in England did not prompt patients to switch providers. Health Affairs, 31(3), 593-601. https://doi.org/10.1377/hlthaff.2011.0810

Law, W. K., Chan, A. H. S., \& Pun, K. F. (2006). Prioritising the safety management elements: A hierarchical analysis for manufacturing enterprises. Industrial Management and Data Systems, 106(6), 778-792. https://doi.org/10.1108/02635570610671470

Mikes, A. (2009). Risk management and calculative cultures. Management Accounting Research, 20(1), 18 40. https://doi.org/10.1016/j.mar.2008.10.005

OSHA. (2018). Safety and Health Topics | Toluene - Occupational Exposure Limits | Occupational Safety and Health Administration. National Journal of Community Medicine, 117-120.

Parand, A., Dopson, S., Renz, A., \& Vincent, C. (2014). The role of hospital managers in quality and patient safety: A systematic review. BMJ Open, 4. https://doi.org/10.1136/bmjopen-2014-005055

Thungjaroenkul, P., Cunmings, G. G., \& Embleton, A. (2007). The impact of nurse staffing on hospital costs and patient length of stay: A systematic review. Nursing Economics, 25(5), 255-265.

Tsai, T. C., Jha, A. K., Gawande, A. A., Huckman, R. S., Bloom, N., \& Sadun, R. (2015). Hospital board and management practices are strongly related to hospital performance on clinical quality metrics. Health Affairs, 34(8), 1304-1311. https://doi.org/10.1377/hlthaff.2014.1282

Wang, H., Fennie, K., He, G., Burgess, J., \& Williams, A. B. (2003). A training programme for prevention of occupational exposure to bloodborne pathogens: Impact on knowledge, behaviour and incidence of needle stick injuries among student nurses in Changsha, People's Republic of China. Journal of Advanced Nursing, 41(2), 187-194. https://doi.org/10.1046/j.13652648.2003.02519.x

Zwanziger, J., Khan, N., \& Bamezai, A. (2010). The relationship between safety net activities and hospital financial performance. BMC Health Services Research, 10(January 2010). https://doi.org/10.1186/1472-6963-10-15 